\title{
ASSESSMENT OF TRACE ELEMENTS BIOAVAILABILITY - INGESTION OF TOXIC ELEMENTS FROM THE ATTIC DUST COLLECTED FROM THE VICINITY OF THE FERRO-NICKEL SMELTER PLANT
}

\author{
Katerina Bačeva Andonovska ${ }^{*}$, Trajče Stafilov ${ }^{1,2}$, Irina Karadjova ${ }^{3}$ \\ ${ }^{1}$ Research Center for Environment and Materials, Macedonian Academy of Sciences and Arts, \\ 1000 Skopje, Republic of Macedonia \\ ${ }^{2}$ Institute of Chemistry, Faculty of Natural Sciences and Mathematics, Ss. Cyril and Methodius University, \\ POB 162, 1000 Skopje, Republic of Macedonia \\ ${ }^{3}$ Faculty of Chemistry and Pharmacy, "St. Kliment Ohridski" University of Sofia, Bulgaria \\ "Corresponding author, e-mail: kbaceva@manu.edu.mk
}

\begin{abstract}
The purpose of this study was to establish total and bioavailable contents of chemical elements in attic dust and their distribution in the area of the town of Kavadarci, Republic of Macedonia, and in this way to evaluate the exposure of population to toxic metals in areas with high industrial influences from the ferronickel smelter plant. The attic dust is derived predominantly from external sources such as aerosol deposits and soil dusting, and less from household activities. From that reason attic dust could be accepted as a tracer of historical aerosol pollution. All attic dust samples were analyzed for total and bioavailable element contents and their distribution in studied area. Several extraction agents recognized as representative for elements bioavailability assessment were applied to attic dust samples under investigations - phosphate buffer solutions that simulate human blood, for the simulation of lung inhalation carbonate buffer was used and $0.1 \mathrm{~mol} \mathrm{l}^{-1} \mathrm{HCl}$ solution to simulate stomach ingestion. A total of 18 elements ( $\mathrm{Ag}, \mathrm{Al}, \mathrm{As}, \mathrm{B}, \mathrm{Ba}, \mathrm{Ca}, \mathrm{Cd}, \mathrm{Co}, \mathrm{Cr}, \mathrm{Cu}, \mathrm{Fe} \mathrm{K}$, $\mathrm{Mg}, \mathrm{Mn}, \mathrm{Ni}, \mathrm{Pb}, \mathrm{Sr}$ and $\mathrm{Zn}$ ) were determined by atomic emission spectrometry with inductively coupled plasma (AES-ICP). The obtained results showed relatively high proportion of toxic elements bioavailability in the attic dusts samples from sites close to the metallurgical activities $(\mathrm{Cr}, \mathrm{Cu}, \mathrm{Mn}, \mathrm{Ni}, \mathrm{Pb}$ and $\mathrm{Zn})$, most probably due to the small size and high reactivity of the particles of attic dust. As might be expected the highest leachable amounts of toxic elements were found for $\mathrm{Ni}, \mathrm{Co}, \mathrm{Cr}$ and $\mathrm{Pb}$ from attic dust in the extraction solution of $\mathrm{HCl}\left(0.1 \mathrm{~mol} \mathrm{l}^{-1} \mathrm{HCl}\right)$ compared with the other 3 extraction media. Discussion on trace elements mobility and bioavailability related to environmental pollution and effects on human health are presented.
\end{abstract}

Keywords: attic dust; trace elements; bioavailability; mobility; Kavadarci

\section{INTRODUCTION}

The increased industrial activities lead to a rising level of urban environmental pollution. Traffic emissions and waste from municipal activities are major anthropogenic problems and health risks in recent years. Rapid increases of toxic metal concentrations in the atmosphere and environment are commonly coupled to the development of exploitative technologies. The contribution of the human factor to this problem is very broad and complex, which leads to feedback processes. Atmospheric deposition of toxic metals is the main subject of many studies and usually takes place in industrialized areas, where exploitation and processing of natural resources (ore, oil, etc.) are performed [1]. Atmospheric deposition poses significant ecological concerns. According to the process of deposition particles can be deposited at the earth's surface in two ways, dry or wet, depending on the phase in which a species strikes the earth's surface and is taken up [2].

The emission of toxic metals into the atmosphere is one of the greatest threats to human health. People are directly exposed to the effects of toxic 
metals through inhalation of airborne microparticles from atmospheric dust [3]. Depth of penetration and deposition of particles depends on their size, the defense capabilities of the respiratory tract and the respiratory pattern [4] which finally also determine the effect to the human health. Chemical elements emitted in the atmosphere by combustion processes usually have relatively high solubility and reactivity; especially under low $\mathrm{pH}$ condition [5]. They are highly mobile and might be carried far away from the sources by wind, depending upon whether they are in gaseous form or as particulates. The samples of dust from attic beams are very useful for continuous and long term monitoring of the content of toxic metals and other toxic components in areas with high industrial activities [6-7] ensuring reliable assessment of the degree of pollution. The term dust usually comprises street dust and house dust [8-12]. However, other types have also been studied in the past. A particular type of house dust - the attic dust is studied in this work. It represents dust deposited in the attics, with reduced (minimized) influence of the householder. The attic dust is derived predominantly from external sources such as aerosol deposits and as a result of soil dusting, and less from household activities [13]. The main advantage of attic dust as sampling material is that its composition remains constant, i.e. chemically unchanged with time. Investigations on attic dust composition and chemistry therefore reveal the average of the historical state of the atmosphere [13-17].

Chemical elements from dust can entered in human bodies via ingestion, dermal contact, or breathing, especially dangerous for children due to the "hand to mouth" activity during outdoor activities in playground and recreational areas [18]. Low tolerance to toxins and easy ingestion of dust through hand-to mouth pathways are serious health risk hazards that could not be ignored for children. The ingestion and inhalation of dust appears to be the main exposure pathway to $\mathrm{As}, \mathrm{Pb}, \mathrm{Cd}, \mathrm{Cr}$ and $\mathrm{Cu}$, which results in high health risk for people living in industrial zones. The most exposed group in the population to air particles are children, the particles penetrate deeper in their lungs as compared to adults because children breathe deeper and faster and they are physically more active. Ingested metals can accumulate in the fatty tissues, affect the nervous system during the period of maximal brain growth [19-20], disrupt the normal functioning of internal organs and act as cofactors for other diseases [19]. Senior citizens, especially those with a weakened cardiovascular and respiratory system are a high risk group, too. Another risk group comprises patients with chronic pulmonary emphysema, asthma or cardiovascular diseases [21]. Therefore the concentration of metals in house dust is a matter of high concern, together with their bioaccessibility, e.g. the fraction most readily absorbed by humans.

Reliable risk assessment through thorough understanding of the nature and extent of the contamination of house dust with metals [19] is an actual problem from both analytical and environmental point of view. Bioaccessibility (a proxy for bioavailability, which is the proportion of the readily absorbed metal in the sample) is another aspect which is very important in modern health risk assessments [22].

Bioaccessibility has the potential to make a significant impact on current risk assessment and comparing and evaluating the physico-chemical processes within the many models and systems that have been developed over the years to measure bioaccessibility and contaminant exposure [23-25].

The significant emission sources that contribute to atmospheric pollution with chemical elements on the territory of the Republic of Macedonia, are predominantly mines and smelter plants [26]. The subject of this study is to investigate the degree of air pollution in the town of Kavadarci and its surrounding through analysis of attic dust samples. Total elements content and their bioavailable fractions (obtained after extraction with different media: phosphate buffer, hydrochloric acid solution and carbonate buffer, simulating human buffers) are determined in attic dust samples and used to evaluate the exposure of the population to toxic elements. In our previous studies it was shown that the most important source of deposition of the toxic elements is the ferro-nickel smelter plant situated in this region, responsible for the presence of high content of $\mathrm{Ni}$, as well as of $\mathrm{Co}, \mathrm{Cr}$ and some other chemical elements in the soil and dust in this area [15, 17, 27-28].

\section{MATERIALS AND METHODS}

\section{Study area}

Results obtained from moss biomonitoring study showed that the appearance of some metals $(\mathrm{Co}, \mathrm{Cr}, \mathrm{Fe}$ and $\mathrm{Ni})$ in the air in the south-central part of the Republic of Macedonia (Figure 1) is related to the activities of the ferro-nickel smelter plant situated near the town of Kavadarci [15, 29-31].

The population in the city of Kavadarci and its environs (about 60,000) is engaged mainly in agriculture (cultivation of vegetables, grapes and wine production). In 1982, a ferro-nickel production plant started the production of ferro-nickel with an annually processing of about 1.5 million tons of ore.

The oldest formations dominate in the investigated area is and they have direction NW-SE and 
belong to the inner parts of the Vardar zone. The Lower Paleozoic metamorphic complex is present with two series: amphibole and amphibolechlorite schists with marbles and phylite layers [27].

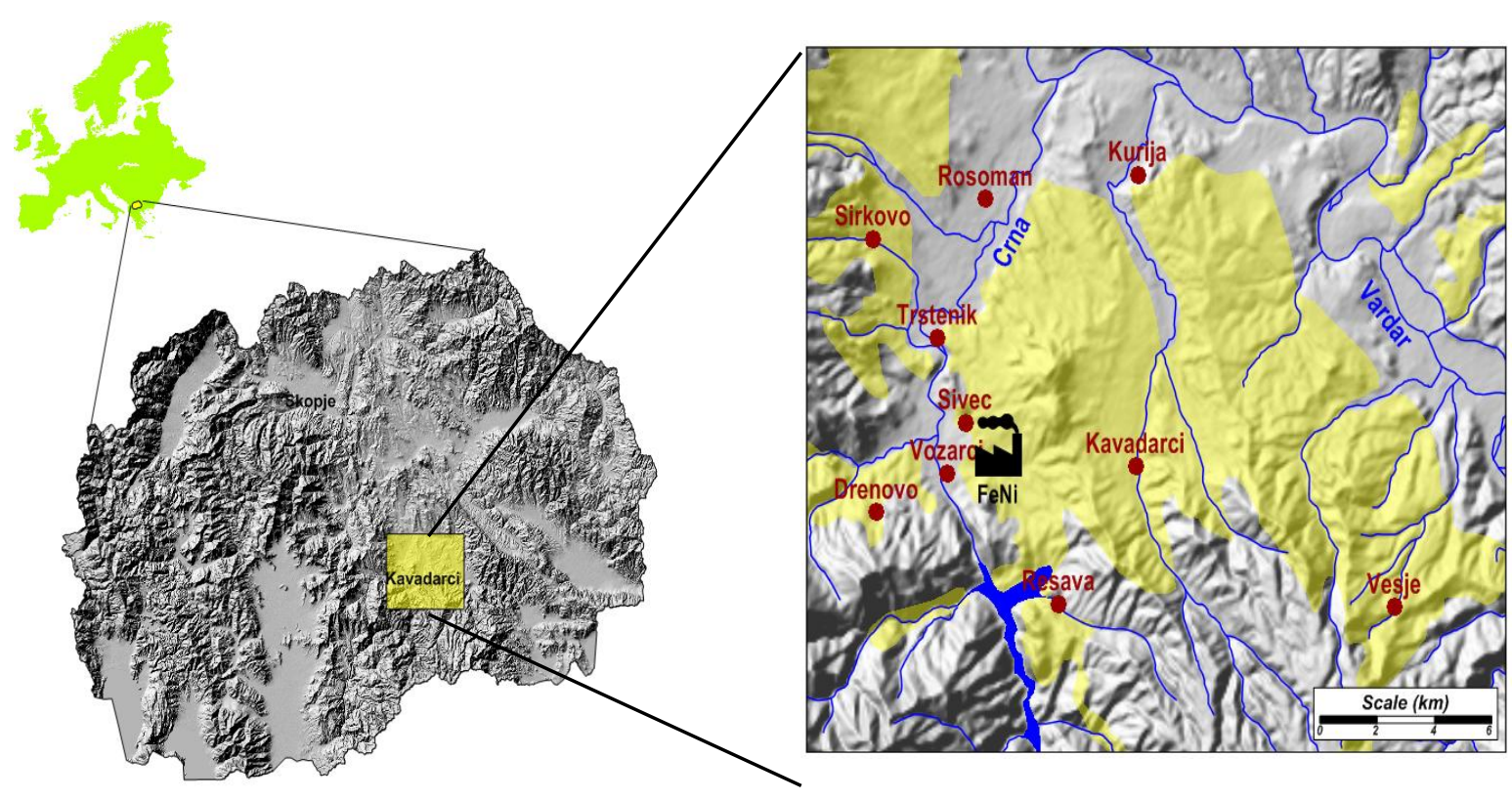

Figure 1. Location of the investigated region and sampling location

\section{Sampling and samples preparation}

Samples of attic dust were collected in the period of October-December 2008 at 10 settlements in the Kavadarci region. In every settlement, attic dust was collected from two or three houses on different sites. The selection of the locations for the sampling area covered the town of Kavadarci, the surrounding area of ferro-nickel smelter plant and the wider environment around $300 \mathrm{~km}^{2}$ and taking into account the direction of the winds and the possible influence of meteorological conditions. The collection of attic dust samples was performed according to the adopted protocol [13, 15-17]. Close to each sample location an old house was chosen with intact attic carpentry. Although some of the selected houses were older than the ferro-nickel smelter plant, most of them were as old as the plant itself. To avoid collecting particles of tiles, wood and other construction materials, the attic dust samples were brushed from parts of wooden constructions that were not in immediate contact with roof tiles or floors [14].

From preliminary studies performed for the same samples of attic dust from Kavadarci and its surroundings it was determined:

a) The total content of chemical elements in the attic dust samples collected from the investigated area [15]; b) Total mineralogical composition of the samples of attic dust [32].

The bioavailability of toxic elements from the dust samples was defined by using different model solutions which were applied to determine leachable and mobile metal concentrations. Four methods were applied for the evaluation of trace elements bioavailability and mobility: (1) extraction with $0.1 \mathrm{~mol} \mathrm{l}^{-1} \mathrm{HCl}$ for $1 \mathrm{~h}$, then suspension was filtered through an acid-resistant filter; (2) extraction with $\mathrm{H}_{2} \mathrm{O}$ for $1 \mathrm{~h}$ then suspension was filtered through membrane (cellulose) filter; (3) extraction of trace elements in a mixed phosphate buffered solution ( $\mathrm{pH}$ in the range 7.35-7.45) that simulate human blood for $1 \mathrm{~h}$ and then filtration trough membrane filter; and (4) extraction of trace elements in a mixed carbonate buffered solution that simulate human lungs and then filtration trough membrane filter.

\section{Instrumentation}

All investigated elements (Ag, Al, As, B, Ba, $\mathrm{Ca}, \mathrm{Cd}, \mathrm{Co}, \mathrm{Cr}, \mathrm{Cu}, \mathrm{Fe}, \mathrm{K}, \mathrm{Mg}, \mathrm{Mn}, \mathrm{Ni}, \mathrm{Pb}, \mathrm{Sr}$ and $\mathrm{Zn})$ were quantified using inductively coupled plasma atomic emission spectrometry (ICP-AES; Varian, 715-ES).

Optimal instrumental and operating conditions are presented in Table 1. Certified reference materials were used to validate the method for all 
considered elements. Results obtained showed very good agreement, the difference between measured and certified values was within $15 \%$. Standard soil reference material (JSAC 0401) was also used to ensure quality control. The measured concentrations agree very well with the recommended values.
The theoretical limit for ICP-AES methods is in the ppm $\left(\mu \mathrm{g} \mathrm{ml}^{-1}\right)$ range for the majority of elements. The determination limits achieved for all studied elements are in the typical range for ICP-AES measurements, relative standard deviations varied between 3 and $12 \%$ for all measured elements.

Table 1. Instrumentation and operating conditions for the ICP-AES (Varian, 715-ES) system

\begin{tabular}{|c|c|c|c|}
\hline \multicolumn{4}{|c|}{ RF generator } \\
\hline \multicolumn{2}{|c|}{ Operating frequency } & \multicolumn{2}{|c|}{$\begin{array}{l}40.68 \mathrm{MHz} \text { free-running, air-cooled RF } \\
\text { generator }\end{array}$} \\
\hline \multicolumn{2}{|c|}{ Power output of RF generator } & \multicolumn{2}{|c|}{$700-1700 \mathrm{~W}$ in $50 \mathrm{~W}$ increments } \\
\hline \multicolumn{2}{|c|}{ Power output stability } & \multicolumn{2}{|c|}{ Better than $0.1 \%$} \\
\hline \multicolumn{4}{|c|}{ Introduction area } \\
\hline Sample nebulizer & & \multicolumn{2}{|l|}{ V-groove } \\
\hline Spray chamber & & \multicolumn{2}{|c|}{ Double-pass cyclone } \\
\hline Peristaltic pump & & \multicolumn{2}{|c|}{$0-50 \mathrm{rpm}$} \\
\hline Plasma configura & & \multicolumn{2}{|c|}{ Radially viewed } \\
\hline \multicolumn{4}{|c|}{ Spectrometer } \\
\hline Optical arrangem & & \multicolumn{2}{|c|}{ Echelle optical design } \\
\hline Polychromator & & \multicolumn{2}{|c|}{$400 \mathrm{~mm}$ focal length } \\
\hline Echelle grating & & \multicolumn{2}{|c|}{94.74 lines $/ \mathrm{mm}$} \\
\hline Polychromator pu & & \multicolumn{2}{|l|}{$0.51 \mathrm{~min}^{-1}$} \\
\hline Megapixel CCD & ctor & \multicolumn{2}{|c|}{1.12 million pixels } \\
\hline Wavelength cove & & \multicolumn{2}{|c|}{$177 \mathrm{~nm}$ to $785 \mathrm{~nm}$} \\
\hline \multicolumn{4}{|c|}{ Conditions for program } \\
\hline RFG power & $1.0 \mathrm{~kW}$ & Pump speed & $25 \mathrm{rpm}$ \\
\hline Plasma Ar flow rate & $151 \mathrm{~min}^{-1}$ & Stabilization time & $30 \mathrm{~s}$ \\
\hline Auxiliary Ar flow rate & $1.51 \mathrm{~min}^{-1}$ & Rinse time & $30 \mathrm{~s}$ \\
\hline Nebulizer Ar flow rate & $0.751 \mathrm{~min}^{-1}$ & Sample delay & $30 \mathrm{~s}$ \\
\hline Background correction & Fitted & Number of replicates & 3 \\
\hline
\end{tabular}

\section{Statistical analysis of the data}

Principal component analysis (PCA) is a statistical method to classify the relations between the measured variables, i.e. it linearly compresses a set of main data to an essentially smaller set of new, uncorrelated variables which represent nearly all information in the main data set. Meanwhile, understanding and working with a small set of uncorrelated variables is much easier than working with a large set of correlated variables. In the present study, PCA was carried out in PAST 3.04 for Windows. In addition, spatial correlation analysis was applied for each variable to select the most appropriate method of interpolation. In particular the obtained results by the method of PCA showed that in the score plots significant correlation exists between the types of extraction.

In the descriptive statistics it was used the coefficient of variance $(\mathrm{CV} \%)$ instead of Variance, to characterize the behaviors of the data. Some statistical parameters like skewness (A) and kurtosis (E) are shown in the Table 3. From the values of A and $\mathrm{E}$, it is shown that the data more or less are following the normal distribution. Is it because there is a constant pollution level in all the area?

\section{RESULTS AND DISCUSSION}

The descriptive statistics of the analyzed element concentrations in the attic dust samples collected in 10 houses from the investigated area (Figure 1) are summarized. The average values for the content of all analyzed elements $(\mathrm{Ag}, \mathrm{Al}, \mathrm{As}, \mathrm{Ba}$, $\mathrm{Ca}, \mathrm{Cd}, \mathrm{Co}, \mathrm{Cr}, \mathrm{Cu}, \mathrm{Fe}, \mathrm{K}, \mathrm{Mg}, \mathrm{Mn}, \mathrm{Ni}, \mathrm{Pb}, \mathrm{Sr}$ and $\mathrm{Zn}$ ) and their minima and maxima in the attic dust samples as well as the basic statistics are presented in the Table 2 and 3. The spatial distribution of the content of some of the analyzed elements $(\mathrm{Co}, \mathrm{Cr}$, $\mathrm{Ni}$ and $\mathrm{Zn}$ ) is presented in Figure 2.

It is known that in the studied area, the main source of toxic metals in the air was the dust emitted from the ferro-nickel smelter plant. Namely, the dust from this facility represents the microparticles of ore that are processed as well as the dust from the waste 


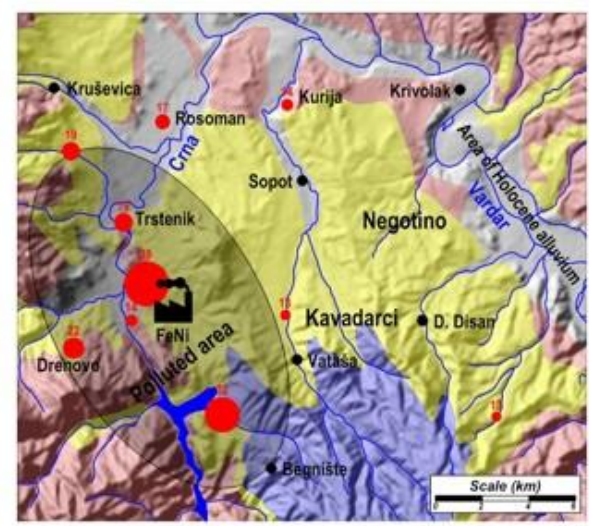

a) $\mathrm{Co}$

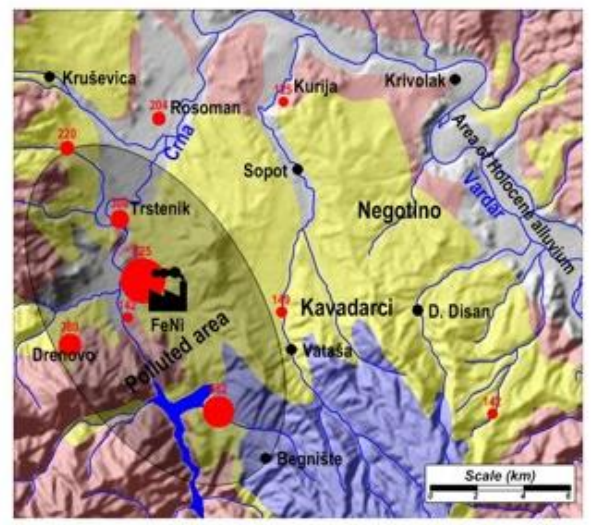

c) $\mathrm{Ni}$

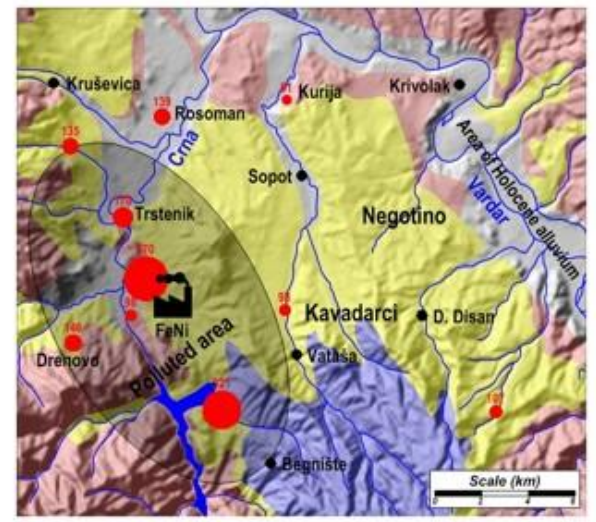

b) $\mathrm{Cr}$

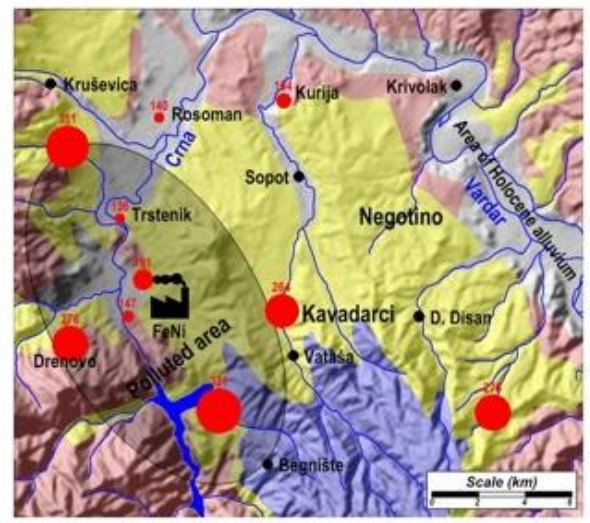

d) $\mathrm{Pb}$

Figure 2. Spatial distribution of the content of: (a) $\mathrm{Co}$, (b) $\mathrm{Cr}$, (c) $\mathrm{Ni}$ and (d) $\mathrm{Pb}$

gases from the ferro-nickel smelter plant. The contents of most of the toxic elements are substantially higher than their natural representation in the surrounding rocks and soils [27-28]. The ferro-nickel smelter plant uses ore that contains between $1 \%$ and $2.5 \% \mathrm{Ni}$, about $0.05 \% \mathrm{Co}, 1-3 \% \mathrm{Cr}$ etc. Therefore, we expect these elements to have significantly higher contents in samples of attic dust compared to their content in the soils from the area [27-28].

The previous studies, moss biomonitoring and attic dust investigations [15, 29-30] conducted in this area defined the anthropogenic group of the following elements: $\mathrm{Cd}, \mathrm{Co}, \mathrm{Cr}, \mathrm{Fe}, \mathrm{I}, \mathrm{Ni}, \mathrm{Pb}$ and $\mathrm{Zn}$, present in the air. The distribution of these elements, especially $\mathrm{Ni}$, Co and $\mathrm{Cr}$, shows their increased content in moss and attic dust samples taken from polluted zones in the investigated region. From the mineralogical investigation of the same attic dust samples collected in the Kavadarci region [32] was confirmed that the mineralogical dust composition differs greatly from the typical mineralogical composition of urban dust. It was shown that the serpentinite (chrysotile, lizardite) and amphibole group of minerals (ribecite, tremolite and actinolite) were presented in the attic dust samples from this region. The fact that these minerals are present in the ore processed in the ferro-nickel smelter plant situated in this area and the high content of $\mathrm{Ni}$ in the analyzed attic dust samples confirms that the source of the pollution is the ferro-nickel smelter plant.

The results obtained in the current survey show that the samples which were collected around the ferro-nickel smelter plant are characterized with the highest contents of $\mathrm{Cr}, \mathrm{Ni}$ and $\mathrm{Zn}$. Thus, the highest content of $\mathrm{Ni}\left(825 \mathrm{mg} \mathrm{kg}^{-1}\right)$ was found in the attic dust samples that were collected from the houses in the village of Šivec the nearest villages to the smelter plant (Table 2). Also, very high content of $\mathrm{Ni}$ was found in the houses form the village of Resava (562 $\mathrm{mg} \mathrm{kg}^{-1}$ ), and the villages of Drenovo and Trstenik with the contents of 389 and $308 \mathrm{mg} \mathrm{kg}^{-1}$, respectively. Similar, high contents were found for $\mathrm{Cr}$ and $\mathrm{Mn}$. The contents of $\mathrm{Cr}$ in the houses from Šivec, Resava, Drenovo and Trstenik were 370, 321, 146 and $170 \mathrm{mg}$ $\mathrm{kg}^{-1}$, respectively. The values for the content of $\mathrm{Pb}$ in attic dust samples varied in the range of 136 to 321 $\mathrm{mg} \mathrm{kg}^{-1}$ (Tables 2 and 3). For the comparison, the average contents of these elements in the surrounding soils are much lower: $74 \mathrm{mg} \mathrm{kg}^{-1}$ for $\mathrm{Ni}, 55 \mathrm{mg} \mathrm{kg}-1$ for $\mathrm{Cr}, 15 \mathrm{mg} \mathrm{kg}^{-1}$ for $\mathrm{Co}$ and $21 \mathrm{mg} \mathrm{kg}^{-1}$ for $\mathrm{Pb}$. 
Table 2. The total content of investigated elements in attic dust samples collected from various setlements (in $\mathrm{mg} \mathrm{kg}^{-1}$ )

\begin{tabular}{cccccccccccccccccc}
\hline Location & $\mathbf{A g}$ & $\mathbf{A l}$ & $\mathbf{A s}$ & $\mathbf{B a}$ & $\mathbf{C a}$ & $\mathbf{C d}$ & $\mathbf{C o}$ & $\mathbf{C r}$ & $\mathbf{C u}$ & $\mathbf{F e}$ & $\mathbf{K}$ & $\mathbf{M g}$ & $\mathbf{M n}$ & $\mathbf{N i}$ & $\mathbf{P b}$ & $\mathbf{S r}$ & $\mathbf{Z n}$ \\
\hline Sivec & 1.73 & 14124 & 14.5 & 295 & 33063 & 8.16 & 39.0 & 370 & 46.0 & 37973 & 12799 & 3448 & 680 & 825 & 191 & 126 & 314 \\
Drenovo & 6.11 & 29311 & 12.6 & 36 & 27024 & 3.75 & 21.5 & 146 & 43.9 & 39497 & 11263 & 955 & 445 & 389 & 276 & 51 & 353 \\
Trstenik & 1.29 & 11648 & 18.0 & 358 & 20697 & 9.33 & 19.4 & 170 & 32.3 & 33056 & 15391 & 6392 & 414 & 308 & 136 & 152 & 296 \\
Kavadarci & 4.71 & 24789 & 20.5 & 435 & 32549 & 14.49 & 13.4 & 98 & 52.4 & 39659 & 12616 & 4490 & 460 & 149 & 264 & 203 & 395 \\
Vozarci & 8.96 & 31882 & 27.6 & 460 & 29226 & 7.34 & 14.4 & 98 & 42.7 & 30592 & 14402 & 7417 & 574 & 142 & 147 & 214 & 313 \\
Sirkovo & 6.07 & 30055 & 16.1 & 258 & 30573 & 13.8 & 19.2 & 135 & 63.7 & 31989 & 13051 & 4179 & 646 & 220 & 311 & 147 & 491 \\
Rosoman & 1.62 & 35213 & 24.2 & 484 & 31082 & 10.7 & 16.7 & 139 & 58.5 & 65157 & 20126 & 6541 & 495 & 204 & 140 & 198 & 418 \\
Kurija & 6.73 & 35612 & 10.9 & 309 & 15346 & 6.70 & 14.3 & 81 & 45.3 & 27947 & 14230 & 1266 & 511 & 125 & 164 & 138 & 293 \\
Resava & 3.72 & 27756 & 18.2 & 342 & 34670 & 11.3 & 32.0 & 321 & 53.7 & 45346 & 12476 & 5225 & 570 & 562 & 321 & 177 & 530 \\
Vešje & 3.32 & 31066 & 31.3 & 416 & 32883 & 8.42 & 13.0 & 107 & 44.7 & 36900 & 13593 & 1680 & 447 & 142 & 276 & 165 & 420 \\
\hline
\end{tabular}

Table 3. Descriptive statistics for the total content of the attic dust samples from the Kavadarci and it's environ (in $\mathrm{mg} \mathrm{kg}^{-1}$ )

\begin{tabular}{cccccccccccc}
\hline Element & $\boldsymbol{N}$ & Mean & Median & Min. & Max. & P10 & P90 & CV \% & Std. Dev. & A & E \\
\hline $\mathbf{A g}$ & 10 & 4.43 & 4.21 & 1.29 & 8.96 & 1.46 & 7.85 & 1.74 & 2.54 & 0.34 & -0.78 \\
$\mathbf{A l}$ & 10 & 27146 & 29683 & 11648 & 35612 & 12886 & 35412 & 3.32 & 8188 & -1.17 & 0.36 \\
$\mathbf{A s}$ & 10 & 19.4 & 18.1 & 10.9 & 31.3 & 11.8 & 29.4 & 2.95 & 6.57 & 0.63 & -0.47 \\
$\mathbf{B a}$ & 10 & 339 & 350 & 36.2 & 484 & 147 & 472 & 2.61 & 130 & -1.41 & 2.71 \\
$\mathbf{C a}$ & 10 & 28711 & 30828 & 15346 & 34670 & 18021 & 33866 & 4.66 & 6161 & -1.46 & 1.45 \\
$\mathbf{C d}$ & 10 & 9.41 & 8.87 & 3.75 & 14.5 & 5.22 & 14.2 & 2.86 & 3.29 & 0.06 & -0.27 \\
$\mathbf{C o}$ & 10 & 20.3 & 17.9 & 13.0 & 39 & 13.2 & 35.5 & 2.34 & 8.66 & 1.49 & 1.43 \\
$\mathbf{C r}$ & 10 & 167 & 137 & 81 & 370 & 90 & 345 & 1.70 & 98 & 1.53 & 1.17 \\
$\mathbf{C u}$ & 10 & 48.3 & 45.6 & 32.3 & 63.7 & 37.5 & 61.1 & 5.40 & 8.95 & 0.09 & 0.24 \\
$\mathbf{F e}$ & 10 & 38812 & 37437 & 27947 & 65157 & 29270 & 55251 & 3.67 & 10581 & 1.90 & 4.46 \\
$\mathbf{K}$ & 10 & 13995 & 13322 & 11263 & 20126 & 11869 & 17758 & 5.72 & 2448 & 1.93 & 4.69 \\
$\mathbf{M g}$ & 10 & 4159 & 4334 & 955 & 7417 & 1110 & 6979 & 1.80 & 2305 & -0.14 & -1.37 \\
$\mathbf{M n}$ & 10 & 525 & 503 & 414 & 680 & 430 & 663 & 5.83 & 90 & 0.61 & -0.84 \\
$\mathbf{N i}$ & 10 & 307 & 212 & 125 & 825 & 134 & 694 & 1.34 & 229 & 1.58 & 2.03 \\
$\mathbf{P b}$ & 10 & 223 & 228 & 136 & 321 & 138 & 316 & 3.01 & 74 & 0.04 & -2.01 \\
$\mathbf{S r}$ & 10 & 157 & 159 & 51 & 214 & 89 & 208 & 3.34 & 47 & -1.15 & 1.98 \\
$\mathbf{Z n}$ & 10 & 382 & 374 & 293 & 530 & 294 & 511 & 4.60 & 83 & 0.62 & -0.76 \\
\hline
\end{tabular}

$N$ - number of samples, Min. - minimal value, Max. - maximal value, P10 - 10 percentile, $\mathrm{P} 90$ - 90 percentile, $\mathrm{CV}$ - coeficient of variation, Std. Dev. - Standard deviation, A - skewness, E- kurtosis

From these results it could be concluded that the population in this region is exposed to the dust with a significantly higher contents of toxic elements as a direct impact of the activities performed in the ferronickel smelter plant. Direct exposure to fine particles of attic dust, which are easily absorbed into the human body through the respiratory system as well as uptake of food that is grown in this region, is a disturbing factor in terms of their health. To assess more realistically the effect on human health, one of the goals of this research was to establish the extractability or bioavailability of these elements from the dust. For that reason, four extraction methods were performed to investigated and see the extractability of toxic and trace elements:

(1) Extraction into hydrochloric acid solution with the concentration of $0.1 \mathrm{~mol} \mathrm{l}^{-1} \mathrm{HCl}$, which simulates gastric juice in the human body;

(2) Extraction with water $(\mathrm{pH}=7)$;

(3) Extraction in a phosphate buffer solution (pH value around 7.35-7.45) that simulate human blood; and

(4) Extraction of toxic elements in carbonate buffer that simulates the human lungs (pulmonary mucus).

The obtained values for the contents of the elements were statistically processed using basic de- 
scriptive statistics. The summarized values of median, minimal and maximal contents of all 10 samples are presented in Table 4. Data for the contents of $\mathrm{Cr}$, $\mathrm{Cu}, \mathrm{Mn}, \mathrm{Ni}, \mathrm{Pb}$ and $\mathrm{Zn}$ for each sample are presented in Figure 3. As can be seen the highest extractability of the toxic elements in samples of attic dust was found in a model solution $0.1 \mathrm{~mol} \mathrm{l}^{-1} \mathrm{HCl}$, which was used to simulate stomach acid juice.

Heavy metals emitted by smelter plant processes usually have relatively high solubility and reactivity, because of the small sizes of particles on which they are carried. In addition, from the results the higher leachibility of heavy metals $(\mathrm{Ni}, \mathrm{Co}, \mathrm{Cr}$, $\mathrm{Pb}$ ) from attic dust samples was in this extraction model solution $0.1 \mathrm{~mol} \mathrm{l}^{-1} \mathrm{HCl}$, compared with the other 3 extraction media. The reasons for the high- est extractability is the low $\mathrm{pH}$ value of the model solution $0.1 \mathrm{~mol} \mathrm{l}^{-1} \mathrm{HCl}$, the other solutions have $\mathrm{pH}$ around 7 or 7.5 .

For the attic dust samples that were extracted with the solution of $0.1 \mathrm{~mol} \mathrm{l}^{-1} \mathrm{HCl}$, the highest median values were obtained for the elements: $\mathrm{Al}, \mathrm{Ca}$, $\mathrm{Fe}, \mathrm{K}, \mathrm{Mg}, \mathrm{Mn}, \mathrm{Ni}, \mathrm{Pb}, \mathrm{Sr}$ and $\mathrm{Zn}$ (Table 4). From these studies it can be concluded that if the dust in any way was entered into the stomach it will pose a significant risk (often by eating unwashed fruits and vegetables) for the human body. The city of Kavadarci and surrounding villages are characterized as agricultural region where the population is mostly engaged in wine culture and making wine, so there is a serious risk to the population health.

Table 4. The calculated contents of the analyzed elements in the extracts of attic dust samples, $N=10$; in $\left(\mathrm{mg} \mathrm{kg}^{-1}\right)$

\begin{tabular}{ccccccccccccc}
\hline & \multicolumn{1}{c}{ Extractions with water } & \multicolumn{3}{c}{ Phosphate buffer solution } & \multicolumn{3}{c}{$\mathbf{0 . 1}$ mol $\mathbf{~ I}^{\mathbf{1}} \mathbf{H C l}$} & \multicolumn{2}{c}{ Carbonate buffer } \\
\hline Element & Md. & Min. & Max. & Md. & Min. & Max. & Md. & Min. & Max. & Md. & Min. & Max. \\
$\mathbf{A g}$ & $<2.5$ & $<2.5$ & $<2.5$ & $<2.50$ & $<2.50$ & $<2.50$ & $<2.5$ & $<2.5$ & $<2.5$ & $<2.5$ & $<2.5$ & $<2.5$ \\
$\mathrm{Al}$ & 14.5 & 8.1 & 32.8 & 14.8 & 9.69 & 22.5 & 1245 & 906 & 1931 & 17.0 & 9.5 & 34.3 \\
$\mathrm{As}$ & $<2.5$ & $<2.5$ & $<2.5$ & $<2.50$ & $<2.50$ & $<2.50$ & $<2.5$ & $<2.5$ & $<2.5$ & $<2.5$ & $<2.5$ & $<2.5$ \\
$\mathrm{~B}$ & 7.3 & 4.8 & 20.6 & 4.92 & 2.11 & 20.11 & 13.5 & 9.9 & 27.9 & 4.6 & 3.0 & 17.0 \\
$\mathrm{Ba}$ & 3.1 & 1.6 & 7.4 & 0.42 & $<0.05$ & 0.85 & 58.0 & 35.3 & 72.0 & 2.4 & 1.6 & 4.5 \\
$\mathrm{Ca}$ & 6057 & 3533 & 14875 & 2271 & 1890 & 2515 & 56978 & 37513 & 114301 & 4486 & 2757 & 12393 \\
$\mathrm{Cd}$ & $<0.5$ & $<0.5$ & $<0.5$ & $<0.50$ & $<0.50$ & $<0.50$ & 3.2 & $<0.5$ & 7.0 & $<0.5$ & $<0.5$ & $<0.5$ \\
$\mathrm{Co}$ & $<0.3$ & $<0.3$ & $<0.3$ & $<0.25$ & $<0.25$ & $<0.25$ & $<0.3$ & $<0.3$ & 3.6 & $<0.3$ & $<0.3$ & $<0.3$ \\
$\mathrm{Cr}$ & $<0.5$ & $<0.5$ & $<0.5$ & $<0.50$ & $<0.50$ & $<0.50$ & 3.6 & 2.9 & 5.5 & $<0.5$ & $<0.5$ & $<0.5$ \\
$\mathrm{Cu}$ & 3.8 & 2.5 & 7.4 & 0.25 & 0.25 & 2.77 & 12.2 & 4.7 & 26.0 & $<0.3$ & $<0.3$ & $<0.3$ \\
$\mathrm{Fe}$ & 14.7 & 7.2 & 36.5 & 5.29 & 0.50 & 12.2 & 932 & 475 & 1444 & $<0.5$ & $<0.5$ & $<0.5$ \\
$\mathrm{~K}$ & 1586 & 932 & 2654 & 1934 & 1217 & 3233 & 2314 & 1386 & 3562 & 1512 & 879 & 2491 \\
$\mathrm{Mg}$ & 786 & 351 & 1048 & 806 & 402 & 917 & 2972 & 1672 & 4181 & 677 & 284 & 947 \\
$\mathrm{Mn}$ & 40.6 & 13.7 & 83.0 & 40.1 & 28.6 & 89.4 & 265 & 156 & 435 & 21.1 & 8.1 & 39.7 \\
$\mathrm{Ni}$ & $<0.50$ & $<0.50$ & 8.1 & $<0.50$ & $<0.50$ & 5.98 & 12.2 & 8.0 & 39.3 & $<0.5$ & $<0.5$ & 7.5 \\
$\mathrm{~Pb}$ & $<1.0$ & $<1.0$ & $<1.0$ & $<1.00$ & $<1.00$ & $<1.00$ & 111 & $<1.0$ & 214 & $<1.0$ & $<1.0$ & $<1.0$ \\
$\mathrm{Sr}$ & 16.7 & 7.3 & 31.7 & 7.68 & 4.81 & 9.21 & 80.8 & 63.8 & 113.8 & 12.5 & 5.8 & 26.4 \\
$\mathrm{Zn}$ & 7.0 & 2.9 & 24.7 & 0.59 & 0.25 & 9.14 & 135 & 89.1 & 236 & 2.6 & 1.6 & 8.7 \\
\hline
\end{tabular}

If we compare the results for all the extraction procedures from each sampling location of attic dust samples with the total content of these elements, the results will be significant. Thus, the content of $\mathrm{Ni}$ in the attic dust samples from the city of Kavadarci was $149 \mathrm{mg} \mathrm{kg}^{-1}$ from which $5.7 \%$ were extracted with a solution of $0.1 \mathrm{~mol} \mathrm{l}^{-1} \mathrm{HCl}$. The total contents of the other analyzed toxic elements for $\mathrm{Cd}, \mathrm{Cu}, \mathrm{Mn}, \mathrm{Pb}$ and $\mathrm{Zn}$ in the attic dust from Kavadarci were 14.5, 52.4, 460, 264 and $395 \mathrm{mg}$ $\mathrm{kg}^{-1}$, respectively, showing significant extractability the same simulation solution $(44,49,55,53$ and $60 \%$, respectively). There were no significant values for the extraction of the toxic elements in the other extraction solutions, except for the extraction with water from which $14 \% \mathrm{Cu}$ and $17 \% \mathrm{Mn}$ were extracted from the same attic dust samples (Table 4, Figure 3).

The village Šivec is located $1.4 \mathrm{~km}$ from the ferro-nickel smelter plant directly exposed to the emitted dust. The total content of $\mathrm{Ni}$ in the dust from this village was $825 \mathrm{mg} \mathrm{kg}{ }^{-1}$. By using the extraction media of water and carbonate buffer only about $1 \% \mathrm{Ni}$ were extracted, while with the extractions with $\mathrm{HCl}$ solution $5 \%$ of $\mathrm{Ni}$ were extracted. For the other elements that were analyzed, again the highest content was extracted with the model solutions of $\mathrm{HCl}$, as follows: $40 \% \mathrm{Cd}, 9.2 \% \mathrm{Co}$, $26 \% \mathrm{Cu}, 64 \% \mathrm{Mn}, 36 \% \mathrm{~Pb}, 62 \% \mathrm{Sr}$ and $28 \% \mathrm{Zn}$ (Table 4, Figure 3). 


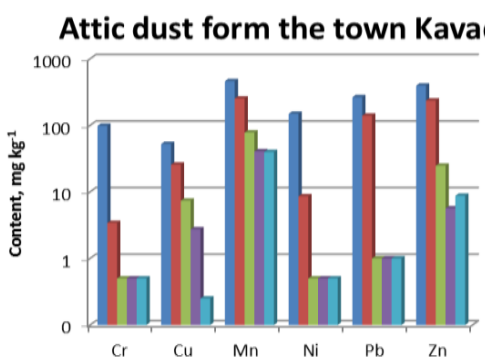

Attic dust from the village Sirkovo

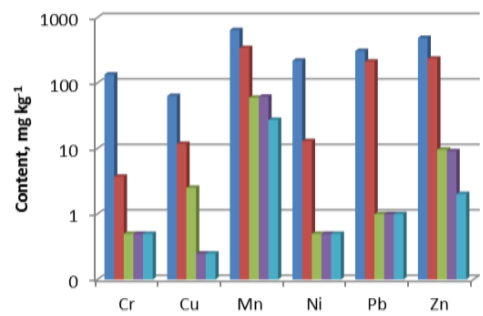

Attic dust from the village Kurija

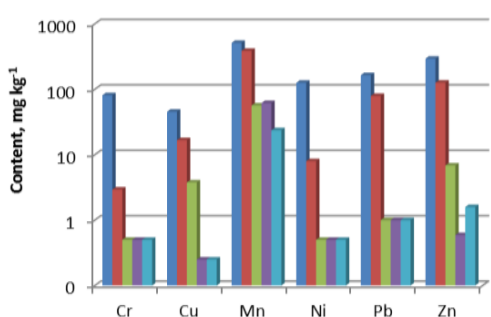

Attic dust from the village Vesje

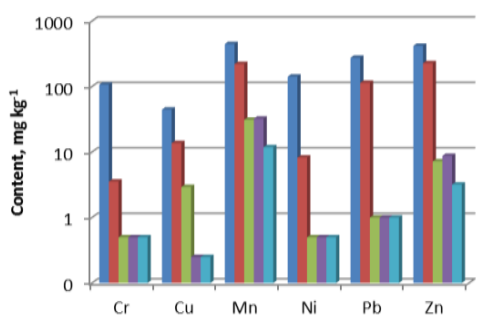

Attic dust from the village Drenovo

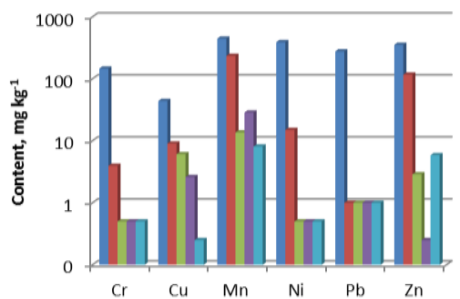

Attic dust from the village Vozarc

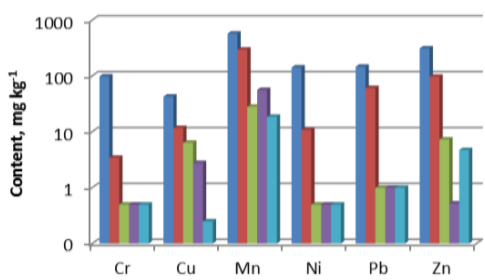

Attic dust from the village Rosoman

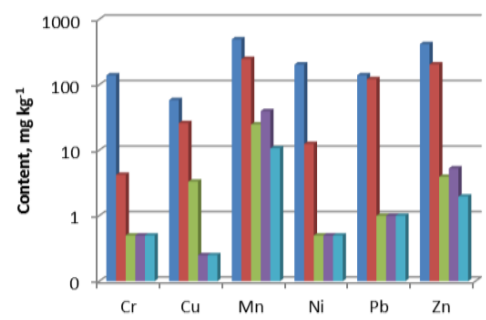

Attic dust from the village Resava

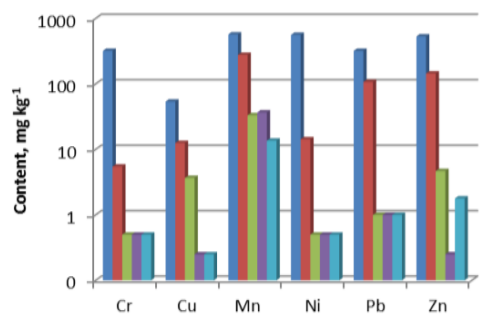

Attic dust from the village Sivec

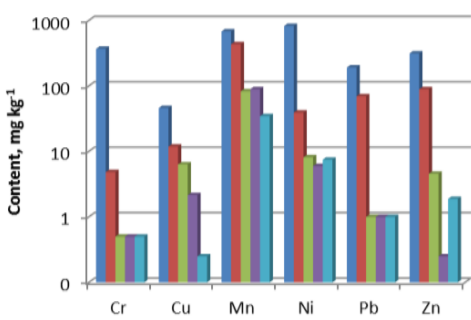

Attic dust from the village Trstenik

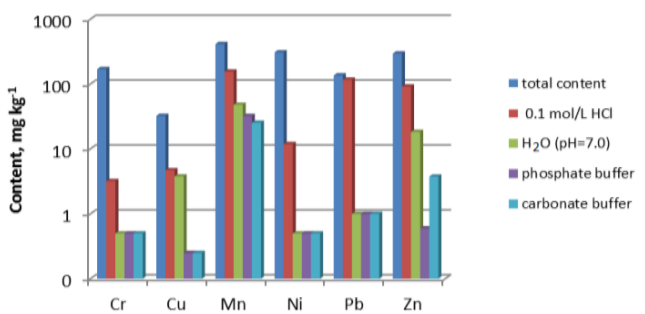

Figure 3. Bioavailability assessment for the $\mathrm{Cr}, \mathrm{Cu}, \mathrm{Mn}, \mathrm{Ni}, \mathrm{Pb}$ and $\mathrm{Zn}$ from the attic dust samples from the town of Kavadarci and surrounding villages 


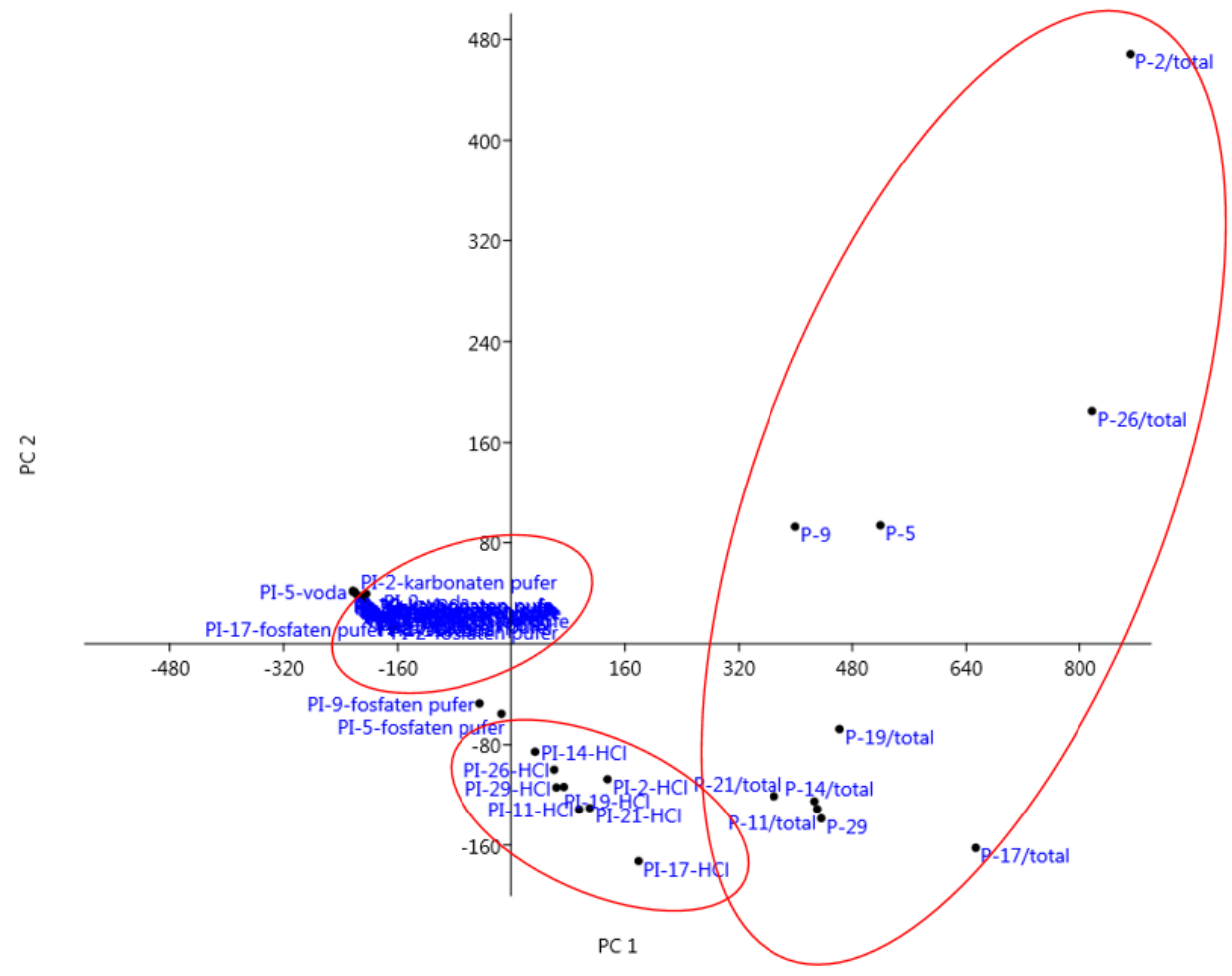

(a) Score plots

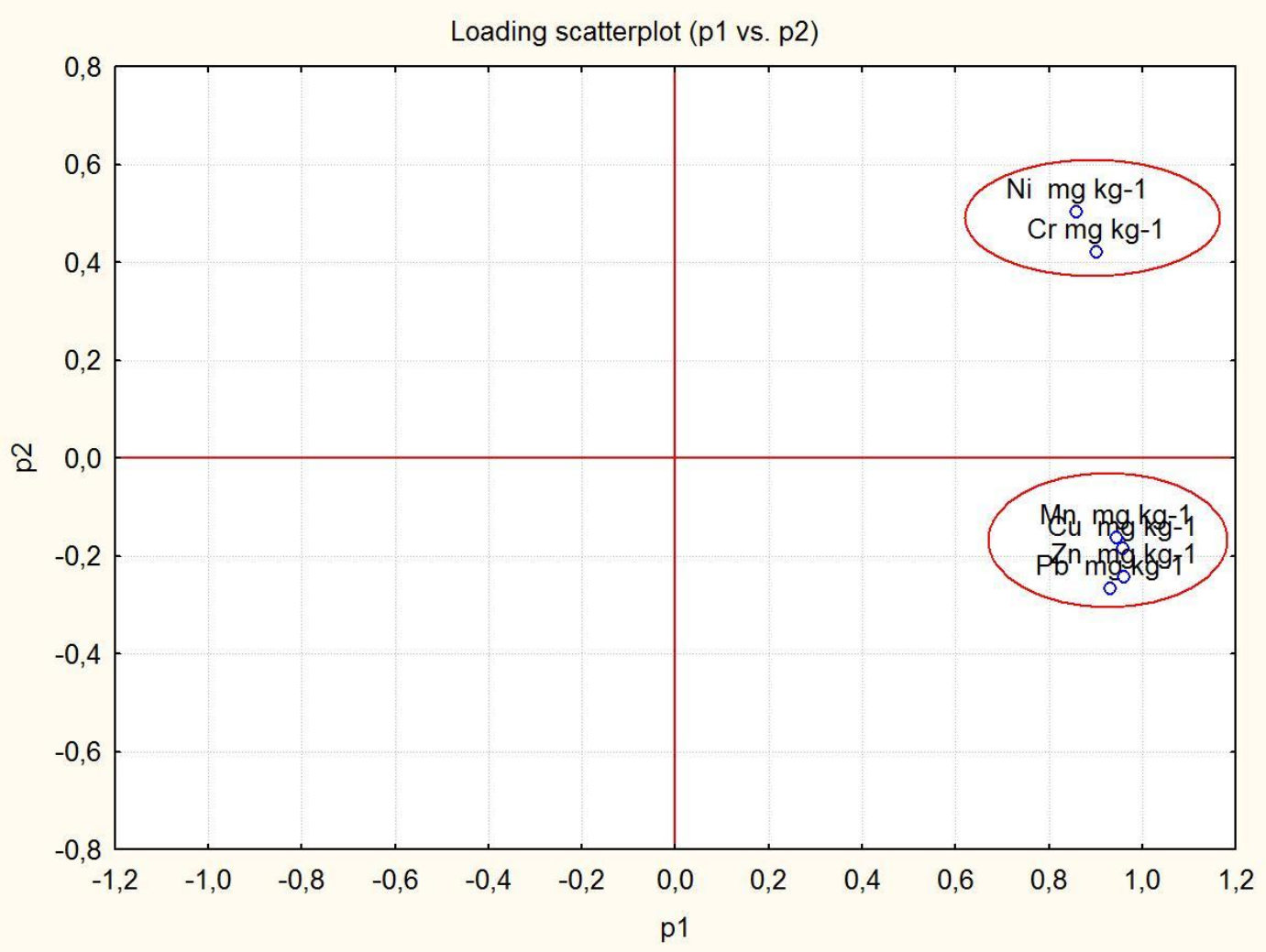

(b) Loading plots

Figure. 4. Principal Component Analysis: (a) Score plots, (b) Loading plots 
Very similar data were obtained by the treatment of the attic dust samples collected from the houses in the village of Vozarci located at a distance of $2 \mathrm{~km}$ from the smelter plant. The total content of the $\mathrm{Ni}$ in the attic dust was $142 \mathrm{mg} \mathrm{kg}^{-1}$, and from the simulated extractions the highest values that were obtained were from the model solution that simulated gastric juice: $7.6 \% \mathrm{Ni}, 3.5 \% \mathrm{Cr}$, $27 \% \mathrm{Cu}, 52 \% \mathrm{Mn}, 42 \% \mathrm{~Pb}, 37 \% \mathrm{Sr}$ and $31 \% \mathrm{Zn}$. Similar values for these elements were established for the samples from the other villages in the vicinity of the smelter plan (Drenovo, Trstenik, Resava, Rosoman, Sirkovo) (Table 4, Figure 3). Because the environment of Kavadarci and the surrounding villages is exposed to high amounts of dust in the air, there is a very high risk of bioavailability - ingestion of toxic elements from the dust by the people, especially those living in the vicinity of the ferro-nickel smelter plant.

From each variables of all samples in the score plots of PCA three groups were distinguished (Figure 4a): the first group consists of the extractions with phosphate and carbonate buffers, a second group includes the extractions with $\mathrm{HCl}$ and the third group the samples with the total content of elements that were completely dissolved. The Loading Plot is used as illustration of the loadings, for the interpretation of relationships among variables. From the Figure $4 \mathrm{~b}$ it can be seen that the correlated variables are for $\mathrm{Ni}$ and $\mathrm{Cr}$ and second related group is between $\mathrm{Cu}, \mathrm{Mn}, \mathrm{Pb}$ and $\mathrm{Zn}$. Namely, the ferronickel smelter plant uses ore that contains between 1 and $2.5 \% \mathrm{Ni}$, about $0.05 \% \mathrm{Co}, 1-$ $3 \% \mathrm{Cr}$, etc. Therefore, these elements have significantly higher contents in samples of attic dust compared to other elements $[15,32]$.

\section{CONCLUSION}

The obtained results showed relatively high bioavailable fraction of toxic elements in the attic dusts samples from sites close to the metallurgical activities $(\mathrm{Cr}, \mathrm{Cu}, \mathrm{Mn}, \mathrm{Ni}, \mathrm{Pb}$ and $\mathrm{Zn}$ ) most probably due to the small size and high reactivity of the particles of the dust. As might be expected the highest leachable amounts were found for $\mathrm{Ni}, \mathrm{Co}$, $\mathrm{Cr}$ and $\mathrm{Pb}$ from attic dust in the extraction solution of $\mathrm{HCl}\left(0.1 \mathrm{~mol} \mathrm{l}^{-1} \mathrm{HCl}\right)$ compared with the other 3 extraction media. The main achievement of this study is evaluation of various model solution to assess bioavailable fraction of chemical elements in attic dust samples in order to evaluate the exposure and risk for the human health. From these investigations it might be concluded that due to the high content of toxic elements in the the attic dust sam- ples from the settlements in an area with ferronickel metallurgical activities and their mobility and bioavailability, there is an impact on human health related to environmental pollution.

\section{REFERENCES}

[1] M. Athar, S. Vohora, Heavy Metals and Environment, New Age International Publishers, New Delhi, (1995).

[2] B. Finlayson-Pitts, N. Pitts, Chemistry of the Upper and Lower Atmosphere, CA: Academic Press, San Diego, (2000).

[3] L. Jarup, Hazards of heavy metal contamination, Brit. Med. Bull., 68 (2003), pp. 167-182

[4] T. Godish, Air Quality, 4th ed., Lewis Publishers, Boca Raton, (2004).

[5] H. Hou, T. Takamatsu, M. K. Koskiwa, M. Hosomi, Trace metal sin bulk precipitation and throughfallin a suburban area of Japan, Atmos. Environ., 39 (2005), pp. 3583-3595.

[6] V. Ilacqua, N. C. Freeman, J. P. Fagliano, J. Lioy, The historical record of air pollution as defined by attic dust, Atmos. Environ., 37 (2003), pp. 2379-2389.

[7] A. M. Tye, E. S. Hodgkinson, B. G. Rawlins, Microscopic and chemical studies of metal particulates in tree bark and attic dust: evidence for historical atmospheric smelter emissions, Humberside, UK. J. Environ. Monitor., 8 (2006), pp. 904912 .

[8] E. B. Culbard, I. Thornton, J. Watt, M. Wheatley, S. Moorcroft, M. Thompson, Metal contamination in British urban dusts and soils, J. Environ. Qual., 17 (1988), pp. 226-234.

[9] J. E. Fergusson, N. D. Kim, Trace elements in street and house dusts: Source and speciation, Sci. Total. Environ., 100 (1991), pp. 125-150.

[10] J. E. Fergusson, The science of global change, the impact of human activities on the environment, in: D. A. Dunnette, R. J. O'Brien (Eds.), American Chemical Society, Washington D.C., (1992), pp. 116-133.

[11] M. S. Dundar, F. Ozdemir, Heavy metal contents of indoor air dust particulate matter from Adapazari, Turkey, Fres. Environ. Bull., 14 (2005), pp. 189-193.

[12] K. M. Ochsenkühn, M. Ochsenkühn-Petropoulou, Heavy metals in airborne particulate matter of an industrial area in Attica, Greece and their possible sources, Fres. Environ. Bull., 17 (2008), pp. 455462.

[13] R. Šajn, Influence of lithology and antropogenic activity on distribution of chemical elements in dwelling dust. Slovenia, Geologija, 43 (2000), pp. 85-101.

[14] R. Šajn, Using attic dust and soil for the separation of anthropogenic and geogenic elemental distributions in an old metallurgic area (Celje, Slovenia), Geochem. Explor. Env. A, 5 (2005), pp. 59-67. 
[15] K. Bačeva, T. Stafilov, R. Šajn, C. Tănăselia, S. Ilić Popov, Distribution of chemical elements in attic dust in the vicinity of ferronickel smelter plant, Fres. Environ. Bull., 20(9) (2011), pp. 2306-2314.

[16] B. Balabanova, T. Stafilov, R. Šajn, K. Bačeva, Distribution of chemical elements in attic dust as reflection of lithology and anthropogenic influence in the vicinity of copper mine and flotation, Arch. Environ. Con. Tox., 61 (2011), pp. 173-184.

[17] T. Stafilov, R. Šajn, B. Balabanova, K. Bačeva, Distribution of heavy metals in attic and deposited dust in the vicinity of copper ore processing and ferronickel smelter plants in the Republic of Macedonia, in: Dust: Sources, Environmental Concerns and Control, L. B. Wouters, M. Pauwels (Eds.), Science Publishers, Hauppauge, NY, 2012, pp 57-98; ISBN: 978-1-61942-566-7.

[18] Y. M. Han, P. X. Du, J. J. Cao, E. S. Posmentier, Multivariate analysis of heavy metal contamination in urban dusts of Xian, Central China, Sci. Total. Environ., 355 (2006), pp. 176-186.

[19] S. T. Tong, K. C. Lam, Home sweet home? A case study of household dust contamination in Hong Kong, Sci. Total. Environ., 256 (2000), pp. 115-123.

[20] G. Chattopadhyay, K. C. P. Lin, A. J. Feitz, Household dust metal levels in the Sydney metropolitan area, Environ. Res., 93 (2003), pp. 301-307.

[21] D. Vallero, Fundamentals of Air Pollution. $4^{\text {th }}$ ed.. Academic Press Elsevier, Amsterdam, Boston, Heidelberg, London, New York, Oxford, Paris, San Diego, San Francisco, Singapore, Sydney, Tokyo, (2008).

[22] A. Turner, K. H. Ip, Bioaccessibility of metals in dust from the indoor environment: application of a physiologically based extraction test, Environ. Sci. Technol., 41 (2007), pp. 7851-7856.

[23] A. G. Oomen, A. Hack, M. Minekus, E. Zeijdner, C. Cornelis, G. Schoeters, et al., Comparison of five in vitro digestion models to study the bioaccessibility of soil contaminants, Environ. Sci. Technol., 36 (2002), pp. 3326-3334.
[24] A. G. Oomen, E. F. A. Brandon, F. A. Swartjes, J. P. A. Lijzen, A. Sips, How can information on oral bioavailability improve human health risk assessment for lead-contaminated soils? Implementation and scientific basis, Epidemiology, 17 (2006), S40-S40.

[25] N. T. Basta, J. N. Foster, E. A. Dayton, R. R. Rodriguez, S. W. Casteel, The effect of dosing vehicle on arsenic bioaccessibility in smelter-contaminated soils, J. Environ. Sci. Hea.l A, 42 (2007), pp. 1275-1281.

[26] T. Stafilov, Environmental pollution with heavy metals in the Republic of Macedonia, Contribution, Sec. Natur. Math. Biotech. Sci., MASA, 35 (2014), pp. 81-119.

[27] T. Stafilov, R. Šajn, B. Boev, J. Cvetković, D. Mukaetov, M. Andreevski, Geochemical Atlas of Kavadarci and the Environs, Faculty of Science, Sts Cyril and Methodius University, Skopje, (2008).

[28] T. Stafilov, R. Šajn, B. Boev, J. Cvetković, D. Mukaetov, M. Andreevski, S. Lepitkova, Distribution of some elements in surface soil over the Kavadarci region, Republic of Macedonia, Environ. Earth. Sci., 61 (2010), pp. 1515-1530.

[29] K. Bačeva, T. Stafilov, R. Šajn, Biomonitoring of nickel air pollution near the city of Kavadarci, Republic of Macedonia, Ecol. Protect. Environ., 12 (2009), pp. 57-69.

[30] K. Bačeva, T. Stafilov, R. Šajn, Monitoring of air pollution with heavy metals in the vicinity of ferronickel smelter plant by deposited dust, Maced. J. Ecol. Envirot., 1 (2012), pp. 47-57.

[31] L. Barandovski, T. Stafilov, R. Šajn, M. Frontasyeva, K. Bačeva, Air pollution study in Macedonia using a moss biomonitoring technique, ICP-AES and AAS, J. Chem. Chem. Eng., 32 (2013), pp. 89-107.

[32] B. Boev, T. Stafilov, K. Bačeva, A. Šorša, I. Boev, Influence of the nickel smelter plant on the mineralogical composition of attic dust in the Tikveš Valley, Republic of Macedonia, Environ. Sci. Pollut. Res., 20 (2013), pp. 3781-3788.

\title{
ПРОЦЕНА НА БИОРАСПОЛОЖЛИВОСТА НА ЕЛЕМЕНТИ ВО ТРАГИ - ВНЕСУВАЫЕ НА ТОКСИЧНИ ЕЛЕМЕНТИ ОД ПРАВ ОД ПОТКРОВНИ ГРЕДИ СОБРАНА ВО НЕПОСРЕДНАТА ОКОЛИНА НА ТОПИЛНИЦА ЗА ФЕРО-НИКЕЛ
}

\author{
Катерина Бачева Андоновска ${ }^{1 *}$, Трајче Стафилов ${ }^{1,2}$, Ирина Караџова $^{3}$
}

\author{
${ }^{1}$ Истражувачки центар за животна средина и материјали, Македонска академија на науките \\ и уметностите, Скопје, Република Македонија \\ ${ }^{2}$ Институт за хемија, Природно-математички факултет, Универзитет “Св. Кирил и Методиј”, \\ п. фах 162, 1000 Скопје, Република Македонија \\ ${ }^{3}$ Факултет за хемија и фармација, Софиски универзитет “Св. Климент Охридски”, Бугарија
}

Целта на ова истражување е да се утврдат вкупната и биорасположлива содржина на хемиски елементи во прав од поткровни греди и нивната дистрибуција во областа на градот Кавадарци, Република Македонија, и на тој начин да се процени изложеноста на населението на токсични метали 
во областа со висока индустриска активност од топилницата за фероникел. Правта на поткровните греди е главно од надворешни извори како што е депонирањето на аеросол и прав од почва, а помалку од куќните активности. Од тие причини правта од поткровни греди може да се прифати како индикатор на историското загадување. Во сите примероци на правта од поткровни греди беше анализирана вкупната и биорасположливата содржина на елементите, за да се определи нивна дистрибуција во испитуваното подрачје. За испитувања на примероците на правта од поткровни греди беа применети неколку екстракциони раствори кои се познати како репрезенатативни за определување на биорасположливоста на елементите: раствор од фосфатен пуфер кој ја симулира крвта на човекот, за симулација на дишни патишта беше користен карбонатен пуфер, како и раствор од $0,1 \mathrm{~mol}^{-1} \mathrm{HCl}$ кој го симулира разградувањето во желудникот. Беа определени вкупно 18 елементи (Ag, Al, As, B, Ba, Ca, Cd, Co, Cr, Cu, Fe K, Mg, Mn, Ni, Pb, Sr and Zn) co помош на атомската емисиона спектрометрија со индуктивно спрегната плазма (АЕС-ИСП). Добиените резултати покажаа висок степен на биорасположливост на токсичните елементи $(\mathrm{Cr}, \mathrm{Cu}, \mathrm{Mn}, \mathrm{Ni}, \mathrm{Pb}$ и $\mathrm{Zn})$ во примероците на правта земена од поткровни греди од куќи во непосредна близина на металуршките активности, што најверојатно се должи на малата големина на честичките на прав и нивната голема реактивност. Како што можеше да се очекува од тестовите на извлекување, во примероците на прав од поткровни греди највисока содржина на токсични елементи беше најдена за $\mathrm{Ni}, \mathrm{Co}, \mathrm{Cr}$ and $\mathrm{Pb}$ во растворот од $0,1 \mathrm{~mol} \mathrm{l}^{-1} \mathrm{HCl}$ во споредба со другите 3 раствори за извлекување. Исто така се презентирани резултатите за мобилноста и биорасположливоста на елементите во траги, кои се поврзани со загадувањето на животната средина и ефектите врз здравјето на луѓето.

Клучни зборови: прав од поткровни греди; елементи во траги; биорасположливост; мобилност; Кавадарци 